\title{
СОЦИЈАЛНО ПРЕТПРИЕМНИШТВО - ПОТРЕБИ И МОЖНОСТИ
}

\section{Кратика сорржина}

Прашањайа на сочијалнотио йреййриемнишииво и неіовойо влијание, како и можносииие за неіово изразување и инсииитуционално обликување и йояярика може яа се анализираай и соілеяуваай оя различни бројни асиекийи на йојавайа.

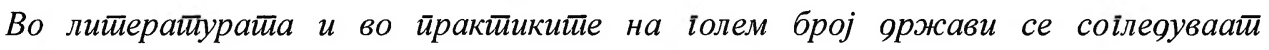
оріанизачиони обличи кои со сисиемска реіулаииива влијаай на йосилно или йослабо изразување на сочијалнойо ирреййриемнишишво. Се анализираай можностийе кои йосйојай за яа се зајакне овој облик на аніажирање и изразување со оілея на йозиииивийе влијанија врз врабойеностиа кои се соілеgани во іолем број оржави.

Како основно ирамање се йосииавува како яа се уреяи областиа на сочијалнойо иррейириемнишишво во рамкиие на иравниой и економскиой сисиемм на еяна яржава. Неойхояно е осознавање на соиијалнойо ирреииириемнишииво, значењетио и улоїа иито іи има, иоосебно во сочијалнайа сфера и можносииите за врабойувањет̄о на кайеіории лииа кои йазарой на йруя не іи йрифаќа или ирейознава. Сочијалнойо иррейириемнишитво различно се изразува и за ирравилно gа се обликува во рамкийе на инсиитиучиите и системой важна е иоояррикайа за неіово иелосно изразување. Клучни зборови: СОЦИЈАЛНОТО ПРЕТПРИЕМНИШТВО, ЗНАЧЕЊЕ,
ПОДДРШКА, ВРАБОТУВАЬЕ

\section{1. Вовеg}

Социјалното претприемништвото како концепт што ги интегрира создавањето на економските и социјалните вредности, присутно е во теоријата и практиката подолг период. Се повеќе се изразува на пошироко национално и глобално ниво и станува се поактуелно со олгед дека остварува значајна општествена мисија.

За суштината и значењето на социјалното претприемништво има различни толкувања и објаснувања: некои го поврзуваат со непрофитни иницијативи и алтернативни стратегии за создавање на општествени вредности; други го опишуваат како општествена одговорност на комерцијалните компании, а трети како постапка и процес на основање на непрофитна организација што потоа позитивно влијае во решавањето на социјални потреби и проблеми.

Може да се дефинира дека социјално претприемништво, претставува организирана дејност со цел за креирање на можности, облици, организации и мерки кои 
резултираат во одржливи општествени вредности и корисности, вработување на лица во производство и продажба на производи или услуги каде што добивката не е единствена или главна цел на активност, односно добивката се користи за вработување на одделни социјално исклучени или ранливи општествени групи и за решавање потреби и проблеми во заедницата.

Социјалното претприемништво претставува процес на креирање на социоекономски структури, врски, институции, организации и мерки кои резултираат во одржливи општествени корисности. Тоа претставува модел на користење на претприемничкото однесување повеке за социјални, а не толку за профитни цели, со други зборови, добивката или генерираниот профит се користи за доброто на одделни социјално исклучени или обесправени општествени групи.

Во изминатите неколку години социјалното претприемништво се здоби со популарно име на глобалната сцена како „нов феномен“, што всушност претставува преобликување на начинот на размислување за креирањето на социјалната вредност. Така социјалното претприемништво го привлече вниманието на поголемиот број фондации и на приватните основачи проширувајќи го своето дејствување во непрофитниот сектор. Со тоа можностите што се создаваат со активностите на социјалните претприемачи, на социјалните претпријатија и социјални задруги или кооперативи се зголемуваат и стануваат предмет на особен интерес. Ова станува уште позначајно кога се согледува влијанието на социјалното претприемништво во создавањето на нови работни места, нови облици на работа и дејствување, нови форми на организација на работа, производство, пласман и остварување приход односно профит кој повторно се наменува за социјални цели и потреби.

Затоа се поставува прашањето како во рамките на општествено економскиот и политичкиот систем да се оформат институционални основи за да се овозможи пошироко изразување на претприемничките иницијативи посебно во социјалната сфера. Исто така се поставуваат прашања кои се можностите што им стојат на располагање на социјалните претприемачи за да се активираат, дали е неопходна општествена поддршка и/или директна поддршка од државата, односно од локалната власт за да се оформат во поголем обем организациони единици од типот на социјални претпријатија, кооперативи, задруги и други форми кои се познати и кои влијаат на зголемување на ефектите во социјалната сфера.

Се поставува прашањето кои се социјалните претприемачи и што ги прави различни во нивниот пристап и работа. Социјалните претприемачи се разликуваат од другите облици на дејствување како што се социјални активисти, корпоративни менаџери за социјална одговорност и професионални иноватори. Социјалните претприемачи се мотивирани од двојна цел: виртуелна мешавина на финансискиот и општествениот доход. Профитабилноста е се уште цел во работата, но не е единствена, а профитот се реинвестира (најчесто во социјални цели) наместо да се испорача на сопствениците.

Ова посебно е важно и за Република Македонија, односно како да се уреди правниот, политичкиот, економскиот и социјалниот систем за да се овозможи изразување на претприемничкиот дух, претприемничките слободи и креации. Прашањето кое се поставува е дали уредувањето на овааа област може да поттикне повеќе поединци да се ориентираат 
кон самовработување и претприемничко изразување во социјалната сфера. Различни се опциите кои се можни па затоа се поставува прашањето како да се уредува оваа област, како да се дава поддршка и кои се потребите за посилно изразување на претприемништвото, а посебно на социјалното претприемништво.

\section{2. Социјални йретиириемачи}

Факт е дека социјалните претприемачи се меѓу нас, и иако се ретки, тие се исклучително успешни во решавањето социјални проблеми, комбинирајќи го чувството и визионерско размислување со реално планирање и осмислување стратегија. Тие се карактеризираат со спој на социјална посветеност и проникливост за деловна работа. Исто така, има многу други социјални активисти, иноватори и креатори на промени кои понекогаш не се соодветни за дефинирање според конкретната дефиниција за социјално претприемништво. Ова е последица на развојниот период што го отсликува трендот кој е присутен, а тоа е човекот да ја преземе одговорноста во свои раце и да го измени тоа што е потребно во општеството за да има подобри услови за живот и работа.

Според дефиницијата за социјално претприемништво претходно наведена се подразбира дека социјалните претприемачи, смислуваат нови идеи за решавање социјални проблеми и за замена на старите непрактични идеи. Тие се креативни и корисни, цврсто решени да ги рашират своите идеи надвор од нивниот круг, а освен тоа, тие поседуваат и високи морални принципи.

Социјалните претприемачи имаат улога на поттикнувачи на промени во социјалниот сектор преку прифаќање на мисија со која би се создале и одржувале социјални вредности (не само приватни вредности), препознавање на новите можности, храбро делување без страв од ограничувањата кои ги налагаат расположливите ресурси, и демонстрирање на зголемена отчетност кон клиентите и за добиените резултати. Социјалното претприемништво има иновативен и одржлив пристап кон системските промени кои ги надминуваат недостатоците на пазарот и ги искористуваат можностите што постојат во општеството.

Што не е социјален претприемач? Социјалниот претприемач не е бизнис претприемач. Овие два термина понекогаш се поистоветуваат и затоа треба да се истакнат разликите. Социјалните претприемачи се посветени на создавање на општествени вредности и за нив финансиската добивка е само средство за постигнување на цел, а никогаш не е цел сама по себе.

Поради нивната општествена мисија, социјалните претприемачи често се споредуваат со други организации во граѓанскиот сектор, често тоа се оние кои се нарекувани невладини организации. Затоа постои потреба и овде да се направи разлика. Социјалните претприемачи се практични и се фокусирани на резултатите, додека организациите на граѓанскиот сектор повеќе се поврзани со процесите и проектите иако и тие можат да делуваат во решавањето на социјални проблеми.

Социјални претприемачи не се добротворни или хуманитарни организации. Социјалните претприемачи не ги прифаќаат хуманитарните модели за решавање на 
социјалните прашања зошто тие веруваат дека со овие модели само се настојува да се намали страдањето и да се справат во дел со социјалните прашања без да се обидуваат да се променат условите кои водат во страдање.

\section{3. Облици на социјално йретийриемнишйво}

Според наведеното може да се заклучи дека социјалното претприемништво ги применува претприемничките начела, како што се: иновативност, превземање на ризик, самодоверба, упорна работа, јасно поставување на цели, одговорност, финансиски и општествени вредности и со тоа преставува уметност на симулантно остварување на финасии и општествена добивка.

Социјалното претприемништво функционира на начин што создава нови патишта за оние поединци во општеството кои се маргинализирани, и со тоа, како катализатор го активира целосниот потенцијал на општеството во кое се живее и гради бизнис. Граѓаните пак, социјалното претприемништво го гледаат како дел од решението на социјалните проблеми, не како давател на одредена услуга, каде што главна цел е профитот. Социјалните претприемачи, од една страна, ги осознават потребите на нивната заедница, се проактивни и одговораат на потребите на иновативни и креативните решенија, без разлика колку нивните ресурси во моментот се на располагање. Од друга страна, важен предуслов за создавање на општествена вредност лежи во разбирањето на динамиката и сложеноста на општеството во кое социјалните претприемачи работат. Со оглед на социјалната мисија, управувањето со ризик во таква средина преставува значително поголем предизвик за социјалните претприемачи, за разлика од традиционалното претприемништво.

Во претприемничката дејност социјалното претприемништво се карактеризира со два типа на активност:

Правата е доходовната дејност, каде што асоцијации на граѓани, социјални претпријатија или задруги кои остваруваат приход-добивка од вршење на стопански и други дејности, ја насочуваат добивката во развој на сопствената дејност, односно профитот се реинвестира за социјални цели;

Вториот облик е социјално вработување, каде што во рамките на социјалните претпријатија, социјалните задруги, граѓанските асоцијации кои самостојно или во партнерство покренуваат програма за социјално вработување за членови на локалната заедница што се остварува на два начина:

1) Преку гарантирање на техничка или финансиска помош на корисниците за поттикнување на сопствена дејност (стимулации за работата на задругите или претпријатијата);

2) Со формирање нов правен субјект со основна цел вработување на што поголем број социјално маргинализирани, загрозени или долготрајно невработени граѓани.

Во совремни услови, социјалното претприемништво одговара на потребите во општеството, на кои ниту владините ниту социјалните институции не можат да дадат одговор, заради нивната бавност и нефлексибилност, но и претесна дефиниција на нивната мисија. Charles Leadbeater (1997) смета дека најголемата причина лежи во тоа што јавниот 
сектор не е толерантен и не прифаќа грешки, не е иновативен и не сака да ги прифати промените на сопствената организација и на работната структура. Според него, треба да се зголеми флексибилноста, а да се намали отпорот на промените.

\section{4. Тийолоіии на социјално йреййриемнищйво}

Според дефиницијата изнесена во претходниот дел, и основните претпоставки за извори, цели и стратегии на социјалните претпријатија, може да се разликуваат четири главни типови на социјално претприемништво:

1. Реформатори на јавниот и непрофитниот сектор кои имаат значително социјално влијание.

2. Трговски претпријатија кои се неконвенционални, бидејќк тие се профитабилни, а кои имаат креативно и позитивно социјално влијание.

3. Општествено базирани катализатори за социјална трансформација без оглед на правниот облик на уреденост.

4. Социјални структури преку кои се реализира социјалното претприемништво правно обликувани како социјални претпријатија, социјални кооперативи или задруги, невладини или непрофитни организации, здруженија и друго.

Сите видови на социјално претприемништво одразуваат два клучни елементи на овој концепт:

-претприемништво - создавање на вредност, која настанува по пат на иновативен начин на дејствување и користењето на моменталните прилики за реализација на вредноста,

-социјално - посветеност кон зголемување на социјалната благосостојба преку помагање на оние на кои им е потребна помош и поддршка.

Може да се заклучи дека: социјалниот претприемач наоѓa практични решенија за социјалните проблеми преку комбинирање на иновации, снаодливост и можности а при тоа ги применува елементите на претприемничкото работење преку кое ги остварува приходите кои потоа ги наменува за социјални цели.

Социјалните претприемачи се посветени на создавање на општествени вредности, тие пронаоѓаат нови процеси, нови производи и услуги и уникатни начини во кои докажаните практики се комбинираат со иновативни начини на решавање на комплексни социјални проблеми. Без оглед на тоа дали полето на нивната акција е развој на претпријатието, здравството, образованието, заштитата на животната средина, работните услови и човековите права, социјалните претприемачи се луѓе кои ги согледуваат проблемите што носат промени и нив ги гледаат како можност да се промени општеството.

Организациите што ги основаат социјалните претприемачи се спротивставуваат на неповолни појави и третмани, особено на социјално запоставените лица. Тие не може да бидат лесно признаени во непрофитниот и во профитниот свет, кој постои. Социјалните претприемачи ги основаат своите организации како профитни ентитети, иако повеќето од нив сѐ уште се конституирани како - не за профит. 
Избраната правна форма на која социјалното претприемништво базира е само продолжување на стратешка одлука чија главна улога е да се постигне социјалната цел и мисија кои се определени.

Повеќето социјални претприемачи се прагматични за ограничувањата на пазарната економија и решени се да најдат начини како да го искористат пазарот за да ги поттикне сиромашните и исклучените на активност со користење на тековните економски модели. Повеќето од нив експериментираат со совршени бизнис модели кои им овозможуваат на сиромашните да имаат пристап до широк спектар на технологии - од информатичка и комуникациска технологија и здравствена заштита до чиста вода, електрична енергија, пристојни плати, образование, социјална заштита и тн....

Социјалните претприемачи истовремено вршат функции и во јавниот и во приватниот сектор. Од една страна работат со луѓe чии потреби државата не е во можност да ги задоволи ефикасно со основните јавни добра и услуги. Од друга страна, пак, се бават со недостатоците на пазарот преку создавање пристап до приватните стоки и услуги на пазарите каде трансакциите не се случуваат, затоа што ризикот е премногу голем или мала е финансиска добивка. Со мала пазарна добивка или помош, социјалните претприемачи создаваат нови начини за изградба на одржливи и мирни општества.

Социјалните претприемачи ја согледуваат посакуваната иднина и работат за да се постигне целта и покрај обидите што ги принудуваат да не го сторат тоа. Тие се агитатори и активисти кои ја поддржуваат идејата за постојано и континуирано подобрување.

Социјалните претприемачи се катализатори на процесот на социјална промена и наместо директно наметнување на промената, нивната цел е да се осигураат дека од долгорочен аспект, динамиките на промената ќ водат кон трајна, одржлива социјална промена. За да се катализира процесот на промена, тие мора многу добро да го сфатат контекстот и да бидат во можност да се стават во позиција на другите луѓе, што резултира со подобро сфаќање за постоење на тенденциите, способностите и за силите. Врз база на ова прифаќање, тие наоѓаат креативни начини за повлекување процес на промена оддолунагоре, често постигнувајќи огромно влијание врз минимални инвестиции.

Социјалните претприемачи имаат специјална способност за трансформирање и за заобиколување на нерешливите конфликти и социјални проблеми. Најсоодветниот начин за анализирање на несовладливите конфликти (социјални проблеми) е преку трансформација на конфликтот (менување на социјалната средина, начинот на размислување, обезбедување можности за развој и др.) или преку заобиколување на конфликтот (социјалниот проблем) преку градење нови, релевантни привлекувачи и поддржувачи кои што стануваат подлога за развој на траен социјален процес.

\section{5. Социјалнойо йреййриемнищт̄во и вработуваьейо}

Голем е бројот на луѓето кои не ги уживаат придобивките од економскиот развој и на економската глобализација. Глобалната економија не обезбедува доволен број на работни места за сите оние кои сакаат или можат да работат, ниту пак постои сценарио според кое би дошло до одреден развој на ова поле. Според Меѓународната организација на 
трудот (International Labour Organization - ILO), во 2014 година како резултат на слабиот економски раст 220 милиони мажи и жени во светот официјално се водат како невработени. Покрај тоа една милијарда или повеќе лица се, или вработени на определено време, или се недоволно ангажирани.

Меѓународната организација на трудот ја потенцира клучната улога на претприемачите во однос на вработувањето, а посебно на социјалните претприемачи. Во срцето на процесот на креирање на работни места се претпријатијата, како во општествениот така и во приватниот сектор. Иако најголемиот дел од луѓето претпочитаат да имаат формално вработување, најголемиот број на нови вработувања во последната декада беа неформални вработувања ${ }^{1}$..

Имајќи го предвид големиот и растечки број на луѓе кои бараат пристојна работа и подобар живот, голем е притисокот врз лидерите во државите и во светски рамки за изнаоѓање на решенија за потребите на луѓето низ целиот свет. Политичките лидери во своите кампањи ветуваат креирање на нови работни места и често биваат изгласани или симнати од функција кога овие ветувања нема да бидат исполнети. И покрај тоа што секојдневно се креираат различни механизми за поддршка на овие луѓе кои бараат работа, половина од популацијата на планетата се бори да преживее со помалку од 3 долари на ден, а половина од нив живеат во сурови услови, екстремна сиромаштија и секојдневно страдаат за храна. Глобализацијата се чини влијаеше врз промена на приоритетите на луѓето од потреба за имање работа кон потреба за обезбедување средства за живот. Оваа огромна бројка е главно концентрирана во земјите во развој, но состојбата не е многу поразлична ниту во развиените земји во кои, исто така постои голем број на луѓе кои и покрај тоа што добиваат редовни приходи, сепак се наоѓаат во групата на сиромашни. ${ }^{2}$

Имајќ ја в предвид целокупната состојба, владите во голем број држави постојано се соочуваат со тешки одлуки за тоа како да го подобрат животот на нивните граѓани преку најефикасно користење на средствата од буџетите за отварање нови работни места. Во тој контекст треба да се истакне социјалното претприемништво и социјалните претприемачи кои споделуваат заеднички интереси со лидерите: како поефикасно, поефективно и долгорочно да ги решат тешките социјални проблеми. И покрај оваа заедничка цел, многу малку се остварува и се постигнува оваа соработка.

Така во 2014 година евидентирано е дека во Европа постојат и работат 2 милиони социјални претпријатија кои вработуваат над 12 милиони работници. Импресивен податок кој упатува на потребата позитивните искуства од други средини да се трансферираат во држави, кои, како и Република Македонија, треба да ги ползуваат можностите кои прозлегуваат од социјалното претприемништво.

\footnotetext{
' Report by the Director-General of the International Labor Organization, Reducing the Decent Work Deficit: A Global Challenge 2011

2 Susan Davis (2011), International Board Selection Committee, Ashoka: Innovators for the Public, Social Entrepreneurship: Towards an Entrepreneurial Culture for Social and Economic Development).
} 




Во суштината на претприемничката активност е покренувањето иницијатива, оформување на дејност и сносењето на ризик за успех или неуспех на иницијативата или на инвестициониот зафат. Во основа на секое дејствување е иницијативноста на поединецот и на неговите напори кон создавање и креирање на услови и можности за изразување на бизнис, односно за реализација на идејата или можноста и врз таа основа остварување профит.

Во услови на постоење на високо ниво на невработеност која создава сериозни економски, социјални и други проблеми, секако дека заслужува внимание согледувањето на можностите за намалување на сиромаштијата односно за претприемничко ангажирање на поединците и во тие рамки на социјалното претприемништво.

Кои се можностите за тоа? Или поинаку поставено прашање: дали институциите на системот овозможуваат слобода на изразување и претприемничкото делување и на социјалното претприемништво на поединецот или граѓанинот кој дал согласност за носителите на власта да ги управуваат институциите што се задолжени за создавање на системски можности за претприемничко ангажирање.

Ако се има предвид дека сиромаштијата се дефинира како состојба во која потребите не се соодветно обезбедени, тогаш, недостигот на понуда за ширење на претприемничките можности е сигнал дека сиромаштијата е навлезена и во најсуптилната креативна сфера од каде треба да се понуди излез од тешката состојба. Всушност сиромаштијата е присутна и во креативноста на институциите да продуцираат системски услови и можности за граѓаните да можат претприемнички да се ангажираат и преку социјалното претприемништво да се влијае на намалување на сиромаштијата.

Секако дека излез постои доколку реално се постават и дејствуваат контролните механизами на системот, ако се сфатат сериозно општествените процеси и се иницираат можностите за нивно развивање кон демократските вредности кои постојат во развиените општества. Неопходни се промени во економско-политичкиот систем, негово доградување и усовршување односно оспособување на функцинирањето на институциите на системот по пат на автоматско регулирање на процесите во општеството за да продуцираат позитивни ефекти за опкружувањето. Таквите ефекти ги мотивираат поединците и социјалните претприемачи кон претприемничко однесување во склад со утврдените законитости. Така се оспособува човекот и поединецот кон дејствување во есенцијално-егзистенцијалниот простор и кон рационални активности со што се трансформира и ги напушта нерационалностите, национализмите и другите дефектни појави кои се лимит за развојот на општеството и вредностите во него. Со активација на механизми се создаваат можности за реализација на целите на социјалното претприемништво и тоа: јакнење на социјалната солидарност и кохезија, охрабрување на луѓето да учествуваат во работи од јавен интерес и волонтерска работа, зајакнување на иновативните способности на претпријатијата за решавање на социјални, економски, еколошки и други проблеми, обезбедување дополнителен асортиман на производи и услуги од јавен интерес, развивање нови можности 
за вработување, социјални иновации, обезбедување дополнителни работни места и социјална интеграција и реинтеграција на ранливите групи на пазарот на трудот.

Со реализација на овие цели им се овозможува на корисниците на можностите кои ги дава социјалното претприемништво да остварат корисности. Како корисници може да се јават лица кои се работно способни и на кои им е потребна помош и поддршка за самостојно и продуктивно вработување за нив и за нивните заедници; лица кои остваруваат права или услуги според прописите од системот на социјална заштита; невработени лица според прописите од областа на вработувањето; лица на кои им е потребна помош и поддршка за совладување на материјални и животни проблеми за решавање на социјални економски и други потреби; лица во состојба на ризик и социјално исклучени на кои им е потребна помош и поддршка за нивна социјална инклузија.

\section{7. Мерки за йоэоршка на социјалнойо ӣреййриемнишйво}

Со системско влијание може да се создаваат нови вредности, нови можности кои се препознатливи за претприемчивите луѓе.

За таа цел потребно е во системот да се дефинираат содржината на мерките по одделни фази како и институционалните структури кои ќ ја овозможат институционализацијата на развојот на претпремништвото како постојана потреба и движечка сила на општеството. Тоа се однесува на формирање на социјално претпријатие, како правно лице што работи во социјалната економија чија примарна цел е да постигне општествено влијание, а не да оствари добивка за неговите сопственици или акционери. Социјалното претпријатие работи преку обезбедување добра и услуги за пазарот преку иновативен и претприемачки начин и ја користи својата добивка првенствено за да оствари општествени цели. Се раководи на отворен и одговорен начин во што особено ги вклучува вработените, потрошувачите и акционерите кои се засегнати од неговоте комерцијални активности.

Стимулирањето на поединците и градење клима во државата за поголемо изразување на претприемачите и на социјалните претприемачи е основната компонента што треба да се иницира со цел за создавање нови работни места, нови активни единици во сите сфери на дејствување и човеково живеење. Во тие рамки е неопходно:

1. Олеснување на основањето на социјални претпријатија, редуцирање на формалностите и непотребните администрирања во добивањето на дозволи и согласности за започнување и/или проширување на дејностите и бизнисите;

2. Смалување на трошоците кои се потребни за основање и работење на социјално претпријатие, задруга или друга форма на дејност, како и другите трошоци доколку се обезбедува вработување на повеќе лица;

3. Развој на понуда односно на основи за финансирање на почетоците и натамошното работење на претприемачите, развој на моделот на софинансирање или пак гаранција за инвестирањето во форма на осигурување од ризик, особено за примена на нови технологии и за вработување лица од социјално ранливите категории; 
4. Оформување на едноставен даночен систем и евиденција на приходите и расходите кај социјалните претпријатија, давање поголеми олеснувања за почетоците и првите години од работењето, а особено смалување на даноците за поголемо вработување во социјалните претпријатија и задруги;

5. Посветување поголемо внимание на образовниот процес, поттикнување на младите кон едукација за изработка на бизнис план, план за дејствување и за дефинирање на идеите што ги носат во себе во можности што реално би можеле да бидат потврдени и пазарно остварени;

6. Реедукација на привремено невработените со цел за брзо прилагодување кон новите техники и технологии како и според барањата на пазарот на труд;

7. Офрмување на систем за поттикнување на вработувањето во области со повисоко ниво на ефикасност и доходовност односно примена на системот на активно користење на сите можности за подобри ефекти, вклучувајки и мерки од социјалната политика и активните политики за вработување;

8. Развивање на социјално партнерство меѓу претпријатијата и институциите за едукација и тренинг на лицата кои бараат работа односно прилагодување на знаењата на невработените кон барањата на претприемачите и социјалните претприемачи;

9. Поттикнување на модернизацијата на работата на фирмите со цел за поголема ефикасност и за отварање на нови работни места, односно поддршка на адаптибилноста на претпријатијата кон пазарните барања, особено за извоз и кон потребите на заедницата за поголеми вработувања.

10. Давање еднакви можности за вработување на младите, жените и социјално загрозените лица како и лицата со специфични потреби (хендикепирани), ризичните групи и остранување на експолотацијата на детскиот труд;

11. Дефинирање на изворите на средства за поттикнување на развојот на претприемништвото од финансиски извори од земјата и од странство, а со цел за поголемо вработување, раст и опстојување на социјални претпријатија и задруги;

12. Поттикнување за јакнење на иновативниот процес и примена на нови технологии во малите, средните и социјални претпријатија како и поттикнување на претпријатијата кон извозни активности, а особено на пазарите на Европската унија, како и производство и супституција на производи кои се увезуваат.

Како значаен предуслов за потикнувањето на претприемништвото и малите, средните и социјалните пратпријатија е и финансирањето на претприемничките активности. Во тој контекст треба да се укаже дека банките треба да се активен сервис што ке ги следи претприемничките идеи и ќе го бара сопствениот интерес во растот и опстојувањето на новите претпријатија. Дури и средствата од меѓународни финансиски институции кои во форма на кредини линии се дадени на сервисирање на одделни банки, заради нивната спорост и неорганизираност, како и компликуваните постапки за добивање кредити остануваат недоискористени, што во крајна линија е загуба за општеството во целина.

Банките со кредитната и советодавната улога што можат да ја одиграат и тоа како можат да придонесат во поттикнувањето на претприемачите за нови зафати. Меѓутоа, високите камати што се применуваат и се над нивото на светските каматни стапки се 
дестимулативни за претприемнички зафати (освен за шпекулативни цели и во зоната на сивата економија каде што не е важна цената на капиталот туку само да се исперат парите). Постоењето на повеќе банки во поддршка на претприемачите доведува до поголема конкуренција и до намалување на каматите со што и капиталот како поатрактивен може да поттикне повеќе претприемачи да ги реализираат своите идеи за бизнис.

Мошне е важно да се осмисли врската меѓу научните и стручните институции од една страна и потенцијалните претприемачи од друга страна. Имено, истражувањето и иновациите мошне често се во корелација со научните кадри и институции, но не се за занемарување и поединечните пронајдоци и иновации. Доколку се воспостави спрега на интерес меѓу овие две групации би се поттикнал процесот на креација и дисеминација на иновациите, трансферот на технологиите и врз таа основа создавањето нови работни места во разни домени на активности. Ова особено станува значајно во доменот на информатичките технологии каде што се јавуваат нови форми на активност за што е потребна обука и специфична техника, користење на милтимедиумите и друго.

Трендот на раст на претприемничките зафати кај нас е извесен доколку благовремно се применат мерките и инструментариумот од арсеналот што се применува во развиените земји за поттикнување на вработувањето, прилагодени на спецификите и можностите кои постојат кај нас. Но едно е сигурно, а тоа е дека смалувањето на невработеноста и намалување и искоренување на сиромаштијата е неопходно да биде заедничка грижа на сите органи, организации и институции кои имаат надлежности во креирањето на политиката и со координирани активности да ги реализираат приоритетите за достигнување на оваа цел.

Создавањето на развојна стратегија и систем на мерки за институционално поттикнување на претприемништвото, а посебно на социјалното претприемништво и социјалните претпријатија, оформувањето фондови за поттикнување на инвестициите, а особено за претприемнички намени и во новите технологии и за генерирање на претприемништвото, како општествена култура и потреба, се неопходности кои мора да бидат содржани во развојниот концепт на државата. Таквите мерки треба да имаат приоритет со оглед на ефектите што ги врши претприемништвото и социјалното претприемништво врз смалувањето на сиромаштијата и за потткнување на вработеноста.

Преку уредување на прашања и институционално решавање на основите за дејствување на повеќ организации и субјекти во областа на социјалното претприемништво, прецизно може да се дефинира регулативата и распределба на носители, обврски и одговорности на надлежните органи и институции во доменот на социјалното претприемништво, како и со вклучување на локалната власт, невладиниот сектор и други облици на дејствување, да се покрене потенцијал кој ќе влијае позитивно на растот и развојот, намалување на невработеноста и јакнење на социјалната кохезија, а преку зголемување на можностите за вработување, намалување на сиромаштијата и помал обем на трошоци за социјални намени. Со поттикнување на нови облици и форми на организирање, вработување и работење во оваа сфера се создаваат можности за изразување на социјалните иновации на практична основа и за едукација на граѓаните за нивно користење со што се создаваат услови за поттикнување на економскиот и социјалниот развој. 


\section{Литерапира}

European Center for Not-for-Profit Law (ECNL) \&UNDP (2012): Legal framework for social economy and social enterprises: a comparative report.

European Parliament (2009) Resolution of 19 February 2009 on Social Economy (2008/2250(INI))

European Economic and Social Committee (2008) "The Social Economy in the European Union".

Roger L. Martin, Sally Osberg, (2007),Social Entrepreneurship: The Case for Definition, Copyright, Leland Stanford Jr. University.

Raičević V. Glomazić R. (2012) Značenje i oblici socijalnog preduzetništva, FES, Beograd

Siri Roland Xavier, Donna Kelley, Jacqui Kew, Mike Herrington, Arne Vorderwülbecke (2013): GEM Global Entreprenurship Monitor 2012 Global Report.

UN Global Compact (2012): A Framework for Action: Social Enterprise \& Impact Investing

Susan Davis,(2011) International Board Selection Committee, Ashoka: Innovators for the Public, Social Entrepreneurship: Towards an Entrepreneurial Culture for Social and Economic Development, 
Jovan PEJKOVSKI

\section{ENTREPRENEURSHIP AND SOCIAL NEEDS AND OPPORTUNITIES}

\section{Summary}

The issues of social entrepreneurship and its impact, and the possibilities of expression and institutional shaping and support can be analyzed and reviewed from numerous different aspects of the phenomenon. In literature and in the practices of many countries are perceived organizational forms that with systemic regulation are affecting more or less expression of social entrepreneurship. The possibilities that exist are analyzed to strengthen this form of engagement and expression because of given positive impacts on employment that are observed in many countries.

As a general question that is imposed is how to regulate the field of social entrepreneurship within the legal and economic system of a country. It is necessary the recognition of social entrepreneurship, the importance and the role it has, especially in the social sphere and employment opportunities for the categories of persons that the labor market does not accept or recognize. Social entrepreneurship differently is expressed and properly shaped within the institutions and the systems and it is important to support for its full expression.

Keywords: SOCIAL ENTREPRENEURSHIP, SIGNIFICANCE, SUPPORT, EMPLOYMENT 